Portland State University

PDXScholar

6-13-1977

\title{
The Divorce Experience and its Impact on the Father- Child Relationship
}

\author{
Susan Coffman \\ Portland State University \\ Ellen Lane \\ Portland State University \\ Erika Worth \\ Portland State University
}

Follow this and additional works at: https://pdxscholar.library.pdx.edu/open_access_etds

Part of the Marriage and Family Therapy and Counseling Commons, and the Social Work Commons Let us know how access to this document benefits you.

\section{Recommended Citation}

Coffman, Susan; Lane, Ellen; and Worth, Erika, "The Divorce Experience and its Impact on the Father-Child Relationship" (1977). Dissertations and Theses. Paper 1895.

https://doi.org/10.15760/etd.1894

This Thesis is brought to you for free and open access. It has been accepted for inclusion in Dissertations and Theses by an authorized administrator of PDXScholar. Please contact us if we can make this document more accessible: pdxscholar@pdx.edu. 
THE DIVORCE EXPERIENCE AND ITS

IMPACT ON THE FATHER-CHILD RELATIONSHIP

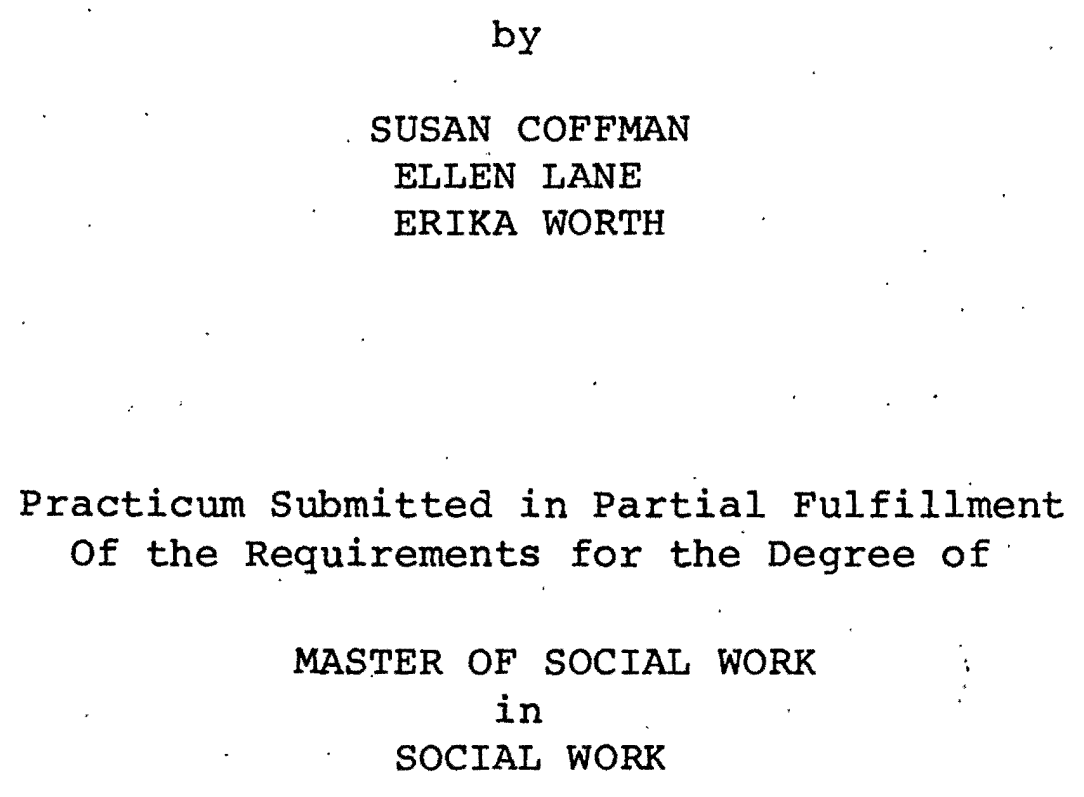

Portland State University

1977 
The Members of the Committee Approve the Practicum of

Susan Coffman, Ellen Lane and Erika Worth

Presented June 13, 1977
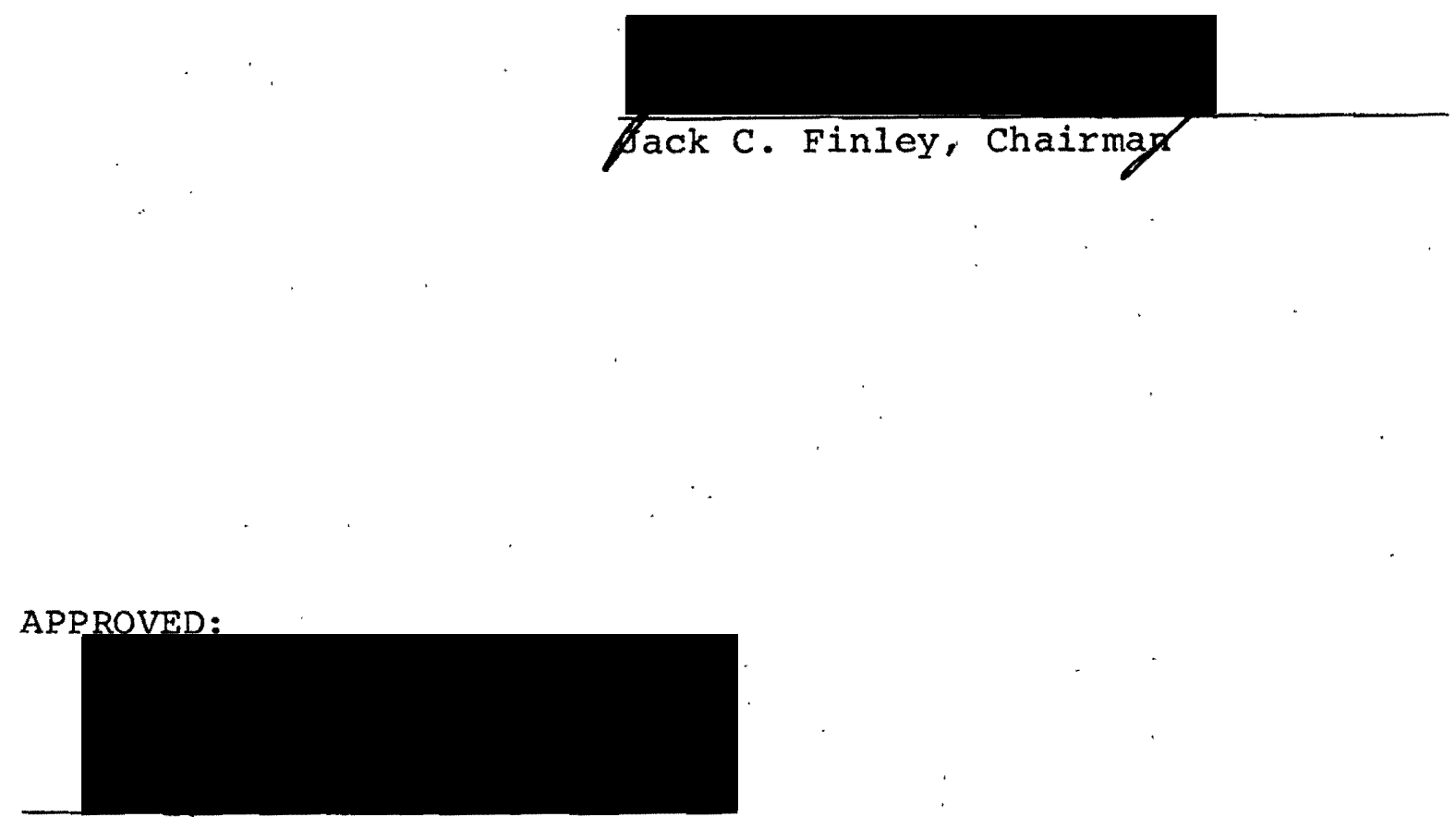

Guido Pinamonti, Head School of Social Work 


\section{ACKNOWLEDGEMENT}

The completion of this project would not have been possible without the cooperation and responsiveness of various professional individuals within the social service agencies in the metropolitan area of Portland. With their efforts, we were able to specifically focus our research on the divorced experience and its impact on the father-child relationship.

We want to particularly thank Solo Center and Parents Without Partners for their willingness to share their agencies' experiences and for helping us obtain our sample population. We are especially appreciative of those individuals who participated in our research by consenting to an interview. These men were consistently candid and helpful in facilitating the resaerch process and we are greatly in their debt.

In addition to these sources, we have been fortunate in having the assistance of Jack Finley and other faculty members at the School of Social Work whose encouragement, support and knowledge contributed to the completion of our research.

One of us wishes to especially thank her husband and daughter for their patience and understanding throughout this project. Our friends and families were supportive and encouraging. 
TABLE OF CONTENTS

PAGE

ACKNOWLEDGEMENTS . . . . . . . . . . . . . . .

CHAPTER

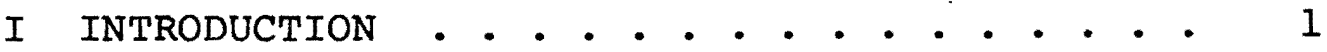

II LITERATURE REVIEW • • . • . . • • • • . . 4

III METHODOLOGY . . . . . . . . . . . . 16

Development and Focus of Research . . 16

Population Parameters . . . . . . 19

Development of an Interview Schedule, Pretest and Administration . . . 21

Analysis of Data . . . . . . . . 23

IV THE DIVORCE EXPERIENCE . . . . . . . . 25

Loss of Lifestyle . . . . . . . 26

Loss of Identity . . . . . . . . 31

Loss of Power . . . . . . . . . 34

Loss of Intimacy . . . . . . . . 41

$\mathrm{V}$ VISITATION . . . . . . . . . . . . . 48

VI THE. EXPRESSIVE FATHER . . . . . . . . . 53 
$\underline{\text { PAGE }}$

VII CONCLUSION . . . . . . . . . . . 67

Impressions . . . . . . . . 68

Critique of study . . . . . . 71

Suggestions for Further study . . 73

Implications for Social Work . . . 74

BIBLIOGRAPHY • • • • . . • • . . • • • • • • • iv

APPENDIX . . . . . . . . . . . . . . . . . viii 


\section{CHAPTER I}

\section{INTRODUCTION}

This project began with the notion that an in-depth examination of perceived changes in the parent-child relationship as reported by the noncustodial father, would be both beneficial to mental health professionals as well as to paraprofessional groups and organizations working with divorced fathers. The authors were aware of much related research pertaining to the children of divorced parents and also the plight of divorced mothers, but felt there to be a lack of data concerning the noncustodial father and thus. identified this area as an important mental health concern.

As soon as the authors had defined the group upon which they intended to base their study, they began to interview professionals working in related fields and an extensive review of the available literature. Among those interviewed were private therapists, the head of a conciliation court, and the director of a professional organization for newly separated and divorced individuals. Interviews were conducted with a member of a nonprofessional group as well. The information that was obtained during initial investigation suggested some global themes affecting most fathers in making the transition from custodial to noncustodial parent. A sense of loss, guilt, powerlessness, alienation, loneliness, 
role confusion, resentment, and competition kept reappearing in statements made during the preliminary interviews. The authors chose to explore these themes through in-depth, open-ended interviews with 15 noncustodial fathers. In giving up our specificity, we hoped to make a more comprehensive statement about the noncustodial father as a subgroup in regard to his experiences and how they affect the role of father.

In choosing to examine the subgroup of the noncustodial parent, his role and his relationship with his child, we began by making certain assumptions about the role of father in contemporary America: Current actions of father are in response to societal needs based on his individual personality traits. These actions include both survival and expressive functions in relation to his children. Although these functions change in regard to historical conditions, we recognize the importance of the father's response to the demands of parenthood at present, because it is through the intense and continuous emotional nature of the parent-child relationship that the child meets the requirement for individual growth and socialization.

Institutions have been established within our society to reward support and sanction the father, which aid him to meet society's expectations of his behavior.

In present times, we can loosely define the father's main continuing function as follows: "To provide material resources for the family, and to serve as an adaptive and 
stabilizing influence reflecting the instrumental orientation of men and their key position of linking the family (child) to its larger social environment."

Divorce or separation generally increases the emotional and physical distance between the child and father, thereby effecting a change in the function of the father and his relationship with his child. 


\section{IITERATURE REVIEW}

In approaching the search of the literature in the area of the divorce experience and its impact on the fathering role, we asked three general questions. First, we asked the question: What is the impact of divorce on the male? What can be generalized from contemporary literature in the field of divorce about its effect on men? Our second question was: How is the role of father defined in contemporary society? How is the father's role described in sociological, psychological and popular literature? The final question addressed in our review of the literature was: What changes occur in the role of father and his relationship to his child after divorce?

The divorce experience is in most cases a highly stressful situation for the male. In a rather ambitious study of the family after divorce, E. Mavis Hetherington, Martha Cox and Roger Cox paid special attention to the problems and coping mechanisms of newly divorced fathers.

The problems were of three types: the practical matters of living day to day in an organized fashion; the emotional stress and changes in self-concept produced by the divorce; and those involving new interpersonal relations as well as relations with their ex-wives and children.

(Hetherington, 1977) 
The study revealed the rather chaotic life style of newly divorced men, struggling to assume tasks previously performed by the wife, and to impose structure without the framework of family life. Men frequently experienced financial problems, and many said their work suffered. The study described their "frenetic search for a new identity immediately after the divorce." (Hetherington, 1977) Divorced fathers in this middle-class population became very active socially, and frequently involved themselves in a variety of self-improvement activities.

Atkin and Rubin discuss the divorce experience for the male. Loneliness is a pervasive theme. Emotional upheaval is expressed in many ways.

Even the solacing arms of another woman give no immunity against the emotional upheavals that follow in the wake of a divorce. You find yourself depressed, self-pitying, full of anger and resentment one moment, guilt-ridden and selfcastigating the next. Your world has come apart at the seams. You feel uprooted, uncertain of your course. As one father put it when asked how he felt after he obtained his divorce, "Man, you 're nowhere." (Atkin, 1976)

Dodson mentions the grief-work which every divorced person must accomplish before rebirth of self-esteem.

Your concept of yourself was to a greater or lesser extent limited by your marriage. Now you go through a period in which a new self-concept is born. (Dodson, 1974)

Dodson also points out that, "divorce means the breakup of a vast web of psychological relationships."

The pervasiveness of loss in the man's life is 
expressed in the following quote from the Male Machine:

What men expect from their wives in return for money, an erect penis, and a little attention, is a full-fledged life support system. (Fasteau, 1974)

In The Naked Nomads, the author presents statistics which convincingly document the diminished physical and mertital health and social adequacy of single males. He contends that a marriage bond is essential for the male to provide self-esteem and meaning in his life; that support and protection of the female is the most definitive masculine function in our society. Other sources point to the fact that the family and marriage relationship are areas where the male's expressive experience are centered.

The various aspects of fathering and role of the contemporary American father are discussed by sociologists and popular writers. Leonard Benson presents a very comprehensive sociological analysis of fatherhood in Fatherhood, A Sociological Perspective.

His main continuing functions are to provide material resources for his family and to serve as an adaptive and stabilizing domestic influence, reflecting the instrumental orientation of men and their key position linking the family to its larger social environment. (Benson, 1968)

Father represents the instrumental orientation, "the disciplined pursuit of goals transcending the immediate situation and encourages resistance to any emotional involvement as an end in itself." The father also provides the expressive dimension in paternal love. 
He promotes a measure of security in his children by being interested in them as no other man is and by his very presence as countless problems arise and are settled. (Benson, 1968)

Henry Biller and Dennis Meredith see a crisis confronting fatherhood and define it in the opening chapter of

\section{Father Power.}

The principal danger to fatherhood today and to the American family for that matter, is that fathers do not have the vital sense of father power they have had in the past.

In Fatherhood, A Sociological Perspective, Benson states, "The American father is almost invisible, perhaps even at home."

The family has become smaller as the surrounding community has enlarged and diversified; father's role is almost inevitably constricted along with the narrowing of general family functions...the father's expressive role usually expands at the same time his instrumental role is being reduced. (Benson, 1968)

Benson points out that patriarchy as a means of maintaining community order has diminished as other community agents assume such functions. Of particular interest to the study of divorced fathers is Benson's conclusion that:

The family has become more important to father as he has become relatively less important to the family. Once father was a prime agent of family strength; now he is often reliant upon it, especially for emotional sustenance.

In an analysis of the role of the American father, LeMasters includes the following ideas:

1. The parental role is a peripheral role for the American male. 
2. There is no biological base or imprinting for the father role at the human level as there is for mother.

3. The father's parental role in the U.S. is peculiarly tied to the pair bond between himself and his wife.

4. The American father is poorly prepared for his fathering role.

LeMasters sees the mother as "Executive Director of the American family," with father kicked upstairs to become "Chairman of the Board."

Fasteau takes a critical view of contemporary parenting roles. His description of father in the intact family has significance for the divorced father.

The role traditionally assigned to fathers and most compatible with the masculine ideal--the benevolent, but authoritarian rule maker and naysayer--is no longer viable in our permissive culture. Still called in primarily to intervene in moments of high crisis or to punish, the father is today regarded as a genuine authority by neither himself nor his children... except for in the limited field of "doing things with" and "being a pal to"'his children (mainly the boys) there are very few models for mutually rewarding relationships between men and their children.

Fasteau talks about challenges in fathering in psychological terms:

For individual fathers, apart from the amount of time spent on the job or career, the most serious obstacle to developing rewarding and useful relationships with their children is an inflexibly masculine personality... one has to confront and deal with their feelings. But to understand and accept another person's feelings 
one must be able to put oneself in his or her place, to experience a little of the feeling oneself. For men who are uncomfortable with and repress their own emotions, especially weak dependent "childlike" emotions, this is difficult.

Men tend to think that the mundane tasks of child care are less significant than gifts or planned activities in creating a close relationship with a child.. Fasteau describes. fathers as not having learned to value the kinds of rewards inherent in parenting. Fathers tend to find self-esteem in their child's objective achievement. He may also tend to be focused on the outcomes of shared activities, rather than enjoy the process. A mania for competition interferes with many fathers' enjoyment of their children. The need to maintain an authoritarian stance tends to interfere with father-child communications. The author concludes, "Most fathers want very much to be close to their children, even if what this means is vague and inchoate, and the estrangement which their actual behavior creates is a painful disappointment."

On a more positive note, Egleson in Parents without Partners concludes:

Fatherhood--with or without custody-- is a creative experience. In a mechanized world that makes it increasingly harder for a man to say with pride, "I did this," it is a genuinely creative opportunity.

The diminished status of the divorced-father is reflected in the very limited amount of literature which deals with the father after divorce or separation. It does appear 
that within the last year an upsurge in interest in the subject has occurred as reflected in an increase in newspaper and magazine articles, and the publication of Part-Time Father, "a book about the separated or divorced father and his relationship to his child."

There is limited social support for the role of divorced father. With two out of five marriages ending in divorce, increasingly at the instigation of the woman, outdated notions of male responsibility and social stigma exist.

It is generally assumed that the man is responsible for the breakup of the family. Since he is nearly always the one to leave the home, whether he wants to or not--he is regarded as the obvious culprit...the stereotype persists of the divorced man as a self-centered, pleasure-seeking male who has walked out on his devoted wife and loving children. (Atkin, 1976)

Biller and Meredith describe divorced fathering in rather pessimistic terms.

Because of the discrimination against the father in divorce and the father's lack of a sense of father power, divorce is a major cause of father neglected children in this country.

There has been limited acceptance of the fact that divorced families represent a widespread life style. With this lack of acceptance has been a failure to define the role of divorced father or address concerns which arise as divorced men attempt to create that role and maintain mutually satisfying relationships with their children. The legal system appears to discriminate against the 
divorced father.

--Men have no control over how the money they send their ex-wives will be spent...

--Men obtain custody of their children in only a small percentage of cases, two or three in some states.

--Men are tossed in jail for violating support orders. But rarely is a woman jailed or even threatened with contempt of court for failing to keep her side of the divorce decree--such as letting her husband visit the children. (Cassidy, 1977)

Father's legal rights are described by Cassidy in his series, "Til Divorce Do You Part."

Judges grant them "reasonable visitation." They are permitted to see their children during certain hours, at certain times of the week, at the discretion of the court--and at the whim of their ex-wives.

"Just as society treats fatherhood as a second-class role, so does the law." (Biller, 1974) Biller does point to increased professional involvement of clinicians in courtrelated matters concerning the father-child relationship. In many cases; father's function after divorce in an entirely new framework, a schedule of visitations rather than daily contact.

This condition is especially hard on the father, who had been actively involved in the care and upbringing of his children, who found deep satisfaction in watching them grow and develop. Such a man feels terribly deprived by his circumscribed contact with the children. (Atkins, 1976)

Father then must function within a structure which is frequently defined by either court or ex-wife. The impact of the divorce experience itself may have affected the man in 
various ways at the psychological level. Weiss in his recent work, Marital Separation, includes the most comprehensive section on the role of the divorced father in literature surveyed. Weiss points out the changes derived from the fact that father is no longer a member of the household. "He is likely to feel out of touch.". It may weaken or end those aspects of the father's relationship that depended on his role in the household as head of the family, protector and provider. Father is no longer seen as a source of physical protection and the role as financial supporter may not be evident to their children.

There are divorced men who, freed from the unbearable strain of an unhappy marriage, find their relationship with their children improved....

Some men on the other hand find the change very hard to take. They do not slip comfortably into this new role. They feel strained and uneasy with the children, and the desire to be part of their lives gets whittled away. (Atkins, 1976)

Atkins develops the idea that father may well fear rejection by his children. In his own unhappiness and anxiety over the new arrangement, he may make inappropriate demands on the children or misinterpret their normal behavior. Fathers may feel they have lost the right to exert authority. An additional unfamiliar task faced by divorced fathers is to solve the problem of communicating and cooperating with the former wife around the interests of the child.

In striving to create a new role for themselves, fathers complain of the difficulties of operating within 
the structure of formal visitation, placing demands on themselves and the child that the visit be perfect. Some react with excessive activity as a result of anxiety or discomfort with intimacy. Egleson points out that many traditional fathers have been totally unaccustomed to spending large amounts of time alone with their children. Egleson points out the difficulties caused by lack of continuity in the relationship:

Bringing Daddy up to date on what has happened since his last visit emphasizes the gap in their lives. And the fact that so much has happened without him inevitably makes a parent feel that he is sitting on the sidelines.

Egleson lists some reasons why father-child relations may diminish after divorce: quarrels with ex-spouse, high cost of weekend or vacation visits; conflict of schedule with desire to establish new family; children may become silent and withdrawn; diminished legal rights and control relative to health, education and welfare; father may wish to avoid a situation allowing for little human dignity.

In "Divorced Fathers," an article in Psychology Today, the authors discuss the relationship with the child in the months following divorce. In most cases men saw less of the children as time passed. In some cases this was the method used to cope with a painful sense of loss. The divorced father was seen to be initially permissive and indulgent, gradually becoming more restrictive. The authors conclude the divorced father's influence on his child diminishes over the years. 
By the end of two years, the divorced fathers usually had less influence on the social, cognitive, and personality development of their children than the mothers, but their continued involvement was a stabilizing influence on the family. (Heatherington, 1977)

Biller and Meredith discuss the potential hazards of angry ex-wives belittling the divorced father and undermining his character in the children's eyes.

Novelist Charles Howe describes the guilt felt by part-time fathers.

He wanted to ask forgiveness because in his own way, now he was being a better father than he had been when he was living at home. He remembered nights, months back, when Jimmy would ask, "Read to me, Daddy? Tell me a story?" and his face burned and he recalled how he had fobbed the child off: "Daddy's tired, I'll do it tomorrow."

He describes the sense of powerlessness experienced

by his fictional father in this passage:

Baker felt a remote anger. It was always the television, the fucking television, running for hours like an unattended water hose that gradually soaks a good lawn into mulch. And now he wasn't around to offer an alternative.

Biller and Meredith describe the potential of the relationship between a divorced father and his child:

Ironically, divorce may help you become a better father. You may spend more time with your child after the divorce than before. Perhaps before the divorce you avoided coming home at night. Now the children are, "on your list of things to do," as one father put it.

Weiss concludes that fathers do remain valuable to their children, respected sources of reserve security and loving interest. In general, the limited material surveyed 
emphasized the legal and social limitations imposed on the role. The author of Creative Divorce Through Social and Psychological Approaches places the divorced father in, "the new role of being without a role." Weiss chooses the image of a "chief of state in exile." The review of the literature provided a framework in which to focuse our inquiry into the impact of the divorce experience on fathering. The implications of loss and the stress experienced during divorce were documented in the sources reviewed. Traditional concepts of fathering were described by authors as well as evidence of ways in which fathering has changed from previous generations. The diminishing of the instrumental functions and increased emphasis on the expressive functions of the father were noted. The rather limited quantity of literature available on the divorced father per se reflected similar concerns to those identified in professional interviewing: how divorced fathers chose to relate to their children; what obstacles they encountered in defining their new relationship; areas of most difficulty, and the ways in which fathers coped with these problem areas. 
CHAPTER III

METHODOLOGY

I. DEVELOPMENT' AND FOCUS OF RESEARCH

While interviews of Mental Health professionals in the metropolitan area yielded generalized impressions regarding the dilemna of divorced fathers attempting to establish relationships with their children, little was known as to the role the divorced fathers assumed, nor was specific or consistent information available that adequately described what changed in the father-child relationship following a divorce. A simultaneous review of the available literature pertaining to divorced fathers supported the researchers' assumptions that this was an area in which little formal research had been done.

Mental Health professionals were able to point out some specific problem areas for the divorced father and his child which had been brought to their attention by their clients, e.g., difficulties in the area of discipline, entertainment and communication. These fathers also seemed to feel that they were powerless to interact with their children in a way that was familiar and comfortable to them; and, that the impact of the divorce on their overall lifestyle had a strong effect on the relationship they wished to 
maintain or establish with their child.

Although these assumptions suggested specific concerns, there were no available surveys or statistical data to validate the assumptions. It was evident that work needed to be done to obtain information about the divorced father's involvement with his child. How divorced fathers choose to relate to their children; what obstacles they encountered in defining their new relationship; which areas created the most difficulty for them, and the ways fathers choose to cope with the difficulties evolving from the new relationship needed to be addressed.

Initially, the researchers attempted to approach the study through the use of a written questionnaire as a measurement tool. The focus of the questionnaire was to encompass several areas:

1. Time structuring between father and child;

2. Changes in discipline patterns;

3. Communication of feelings: how does the father communicate his feelings to his child;

4. Changes in the lifestyle of the father, including change in living situation, friendships, and loss of material possession;

5. Situational changes that affect the father's relationship with his child, such as remarriage, moves, and job changes; and,

6. The part age and sex play in determining the 
relationship the divorced father establishes with his child.

The researchers intended to randomly sample 50 divorced fathers, using the Multnomah County divorce records to obtain participants.

The drawbacks of this method of obtaining data soon became evident. The possibility of obtaining only superficial information appeared possible. Additionally, not enough was known to safely assume that these were the major difficulties confronting the divorced father since the researchers' assumptions were derived from contacts with a limited and biased population. Finally, the use of a written questionnaire might inadvertently leave out some important area of concern not as yet brought to light by either the review of the literature or investigations by other Mental Health professionals.

It was thus determined that a more exploratory approach was needed. This was to be accomplished by extensive and in-depth interviewing of divorced fathers. This method of research would enable the researchers to confirm the importance or unimportance of previously mentioned assumptions, as well as to explore and obtain additional information in areas not as yet addressed. Commonalities expressed by the interviewed fathers could then lead to further research. 


\section{POPULATION PARAMETERS}

The shift from a descriptive design to a more exploratory one forced the researchers to redefine their population. Instead of a random sample of 50 participants, the researchers chose to interview 15 individuals. There was no attempt to obtain a random sample. Instead, several of the participants were members of a local single parents' group, and several were members of a local men's group. The remaining participants were obtained through referrals by persons interested in the research. The researchers recognized that this population could not be considered broad enough so that information obtained was applicable to all divorced fathers, but felt that the overall goal of this research was to raise questions and comment on what may be the divorced father's experience, rather than conclusively validate any particular assumptions.

The median age of the men interviewed was 38 , with the range falling between 31 and 46 years of age. The occupations varied considerably with no two men interviewed falling in the same occupational field. Only one of the men was unemployed. The occupations of the participants were as follows:

- Salesman

- Electrician

- Free-lance photographer

- Mechanic 
- Tri-Met Supervisor

- Community College Administrator

- Newspaper Reporter

- Hospital Administrator

- Parole officer

- Chiropractor Student

- Psychologist

- School Administrator

- Self-employed (Own Business)

- Self-employed (Dry Cleaner)

The educational level of the: interviewed population consisted of seven having completed some post-graduate work, two having graduated from college, five having some college education and one having a high school diploma only.

The median number of years married was twelve, with the range falling between three and twenty-one years. The median number of years divorced was three with the range falling between three months and nine years. Sixty-seven percent of the men interviewed had not remarried, and sixty percent of their former wives had not remarried.

The mean number of children in this sample was 2.07 , with the range falling between one and four. Our of the total number of children, 48 percent were males and 52 percent were females. The median age of the children was 12, with the range falling between 1 and 22 years of age. All but two fathers in the sample contributed financially to their children's care. 
Out of the total population, only one father had a joint custody arrangement. One father had physical, but not legal custody, of one of his four children, with the other three residing with his former wife. Another father had legal custody of one of his two children, with the other one residing with his former wife. The remaining children in the sample resided with the former wives. Out of the total sample, only 33 percent lived in the same town as their children. The out-of-town distances varied from 50 miles to 3,000 miles. At the time of the divorce, ten of the fathers interviewed considered seeking custody of their children and five did not. Of those fathers not having custody, none sought legal custody. The last contact these fathers had made with their children varied from the previous evening to seven years.

III. DEVELOPMENT OF AN INTERVIEW SCHEDULE; PRETEST AND ADMINISTRATION

The Interview Schedule was designed to give the interviewers not only some flexibility, but also an opportunity to follow through on comments made by the interviewees in order to gain new insights and clarification. The Schedule was developed around the original assumptions, but adapted to fit a verbal exchange. Three sections were required. The first section addressed the demographic variables, including such questions as age, occupation, and educational background, number of years married, number of years since 
divorce, age of children, sex of children, number of children and their present living situation. They were also questioned as to their consideration of seeking custody of children at the time of divorce. (Questions No. 1 - No. 13)

The second section probed the father's relationship with his children prior to divorce and the role of father, including his relationship with his own father. (Questions No. 14 - No. 24 )

The third section focused on the father's relationship with his children following the divorce. Specific questions were asked regarding visitation, how the father and the child decided what to do when spending time together, if the child was more difficult to discipline, how important the father felt he was to the child now, if the child knew how the father felt about him, and how he communicated that to him. (Questions No. 25 - No. 32)

Although the questions were designed to encourage the father to talk about his own individual experiences by being open-ended in part, some specificity was included to maintain both order and comparability.

The Schedule was pretested twice prior to the 15 formal interviews. This brought about minor modifications in the structure of the schedule in order to keep interviews more focused.

Each of the 15 formal interviews, as well as the pretests, were tape-recorded with the prior written consent of the interviewees. The interviews averaged one hour in 
length and were primarily done on the campus at Portland State University, with a few done in private homes and businesses.

Two interviewers were present at each interview. One had the role of doing the formal interviewing with the other seeking to clarify information and monitor the tape recorder. The second interviewer also served the function of being a back-up to the primary interviewer. In this way, a check and balance system was implemented.

\section{ANALYSIS OF DATA}

Following the completion of the fifteen interviews, the researchers systematically recorded information from the tapes made in order to put data in a workable form. Each researcher was given a particular task during the editing of each tape. One listed all answers to specific questions on a form made up, which would use only brief and paraphrased data. A second researcher recorded consistent and repetitive themes, which were then listened for on each tape. The third researcher was responsible for recording specific quoted material relevant to the study. These quotes would later be used to verify or support the assumptions or new concerns generalized from the study.

As soon as all the data was broken down, the researchers correlated the responses with the themes on an individual basis. In this way, the researchers had a complete 
composite answer to each question and statement supporting each identified theme. 
THE DIVORCE EXPERIENCE

In an attempt to describe the relationship of the divorced father and his child and to define the role of the noncustodial father, we began with the assumption that certain changes take place at the time of divorce, which set the stage for the new relationship. More specifically, the way in which the noncustodial father experienced divorce, or how it was meaningful to him, would pervade his attempt at maintaining a meaningful relationship with his child. our first step was to establish some picture of how the fathers in our sample perceived the divorce experience and its meaningfulness to them. There appeared to be a consensus that divorce encompassed a series of losses:

I felt like there was a destruction going on of everything I had attempted to build over a period of years. There was a central feeling of having the whole world falling apart.

I didn't know where I was going and didn't know how to get there. What was going to happen to things we had? Where would I stay? Getting asked to leave kind of shakes you up. I didn't know what was going to happen.

In the following section, we have attempted to categorize the expressions of loss in a system such that the impact of the divorce experience can be more closely examined. The categories have been expressed in terms of themes of 
loss: Loss of Lifestyle, Loss of Identity, Loss of Power, and Loss of Intimacy.

\section{LOSS OF LIFESTYLE}

The change in the structure and form of everyday living for the fathers in our study was expressed in statements describing the experience as one of loss. This overall sense of loss seemed to encompass the physical living structure and material possessions attached to the former lifestyle; the daily, weekly, monthly, and yearly time focus of their life, and the relationships set up to enhance that lifestyle (mutual friends/extended family).

The reality when I came back to the house was one TV set and a philodendron.

Many of the fathers expressed grief and anger over the loss of material possessions:

God I was mad. Losing the house, and losing all my furniture, losing the wedding presents from the office, things I had since I was born; isn't there any justice? I wanted my stuff!

I went from a $\$ 47,000$ house to a one-room studio apartment.

I was living totally by myself in a camping trailer.

I left the home. When I was married, I had a brand new 1975 Chrysler which cost $\$ 7,500$. Now, I am driving a 1963 Chrysler which I paid $\$ 1,000$ for.

She got the house and the furniture; she got 
everything--a $\$ 60,000$ house. I have to put up with that in addition to not seeing my own kids.

I didn't feel too bad when she left, but I was upset when she came and got all the furniture.

I Iived with my grandmother; I had to go somewhere and that was the only place I could think of.

For some of the fathers, these losses had more positive ramifications:

The major change is having my own place. I feel liberated from the Work Ethic, since there is less maintenance at this house.

I moved into an apartment with a friend, I could do a lot more. I was pretty much housebound before. I did not have much money.

It's changed for the best; I eat better now. I have a nice apartment.

I don't have to do any fixing up around the house.

Some found the loss of a predictable routine unsettling:

I used to spend all of my free time at home with my daughter, now I spend all of my free time with myself, just trying to keep my mind off of my problems. It is a pretty traumatic experience. It is better to go out and do things than to sit around and contemplate suicide. I got heavy into student government, which I contribute to helping me keep hold of my sanity during those years.

I miss day-to-day responsibilities.

I would work at my office from $6: 00$ to $6: 30$ because the time from 5:00 to $7: 30$ was the most 
painful. Then I would go to a bar and have two doubles and then go home about 7:00; then I could live with myself. I would get a hit about 8:30 when the kids would go to bed and I would find myself pacing.

I had a lot of free time and nothing to do, so I work more, 50 to 60 hours per week.

Everything was always family-oriented. I did not spend a lot of time away from the family on weekends. Now it's different.

Others found the change in routine more positive:

I was single again, and I was free to do whatever I wanted to do, whenever I wanted to.

I was able to go where I wanted. I got involved in some personal growth. There is a real sense of freedom in being able to come and go as I want. I felt a 50-pound weight had been lifted.

I am single again; I can work and have recreation....be social.

My free time is spent the same way as when I was married, except that now I have four nights a week when I am not responsible as a parent.

I started to get out and do a lot more. I started tennis, racquet ball, and travelling around the state.

Now I have time for other activities.

Now I am always on the go. I have a lot of friends, belong to about six organizations and have the freedom to do whatever I want.

I like it (routine) the way it is now. 
The divorce seemed to precipitate the loss of significant relationships, including mutual friends and extended family. These changes were brought on by not only a physical relocation, but by significant others choosing to support one spouse over the other and the exclusion of the newly divorced male from the "marriage milieu."

I have practically a different circle of friends now.

About 50 percent are still friends. 50 percent chose sides. Someone's got to be wrong. My best Army buddy chose up sides, and that was the most painful. They ended up choosing up sides and I lost.

Close shared relationships ended. The church disapproved and friends did not know how to handle me. All of my close relationships that my wife and I shared were destroyed by the divorce.

If they (old friends) said come over for dinner, it was "me and them." They did not know how to handle it.

I moved away; a few close friends are left that I can still visit.

I did not keep any of our mutual friends.

All of my close relationships that my wife and I shared were destroyed by the divorce.

Most of our friends were her relatives. Now those are gone.

The reactions of parents and close relatives was of significance for some of the men we interviewed: 
One of the things that was the most noticeable was the relationship with her family. Immediately, I was surgically removed from their environment. There was a total severance immediately. The whole family excluded me.

The divorce killed that relationship (with wife's family) and it let me know some things about relationships that I just did not want to know.

My parents did not speak to me for over a year.

My parents liked my ex-wife and blamed me for what had happened.

Her parents are now trying to turn the kids against me.

Some of the fathers found that the divorce experience brought about an expansion of their social network which they found to be exciting and more meaningful than that attached to their former situation:

I was involved in a lot of personal relationships that I couldn't have before.

I expanded my relationships!

I was not allowed to have any personal friends. when I was married, unless they were approved of by her. Now I can.

Now I figure that. I have about 80 percent of my old friends back. (Those lost during the marriage.)

For all of the men in our study, divorce was indicative of an overall change in life style--a loss of an old and 
familiar one for a new and often unstable one. Even for. those who found certain aspects of the new life style more fulfilling, there still remained the theme that they were no longer making contact with their children in the structured way they had done prior to the divorce.

For some the family home, car, and household possessions were representative of their accomplishments in life and were symbolic of years of hard work. They expressed feelings of anger and resentment at having to give these up.

Without the familiar responsibilities of daily family life, these fathers were faced with trying to fill empty hours and develop a new routine. He no longer feels comfortable with the old married friends he and his wife had shared, and often close ties with extended family members are damaged.

We now have the picture of the father as cut off from his old structure and looking for a direction in which to evolve. He and his children no longer share the same home, same hours or often times same friends or family ties. He must learn to relate to his child now from a new life framework.

\section{IOSS OF IDENTITY}

For the purposes of this study, we assume the individual's self-concept or identity is composed of the ways in 
which he sees himself in relationship to the rest of his environment. More specifically for the men in our study, identity, in part, came out of their role as husband/father. The interrelationship between the father role and the husband role allows that change in one being precipitated by change in the other.

Several of the men in our study expressed confusion and anxiety in an attempt to find the stability of a new role.

I knew so few divorced people, it was a painful, frightening, and ugly experience. I was totally unsocialized for this experience. A feeling of God, what are you going to be when you grow up.

I dian't know where I fit in, I was just totally an outsider.

I was on the street, I was living on the street, I crashed around with friends and met a lady and eventually moved in with her, so at least I was somewhere.

Being a father was my identity. It was the only thing I have ever done well in my life. I don't mean that in a macho possessive type way, I mean only that I honestly felt I was making a difference in somebody's life, and was doing it instinctively and comfortably and existentially.

The last thing that I wanted to do at 31 was to hang out at Jake's and say, "Hey, lady, what do you think of me."

Three things came all at once, a brand new job in a brand new state, a new start, I was being cut adrift. 
I found it difficult to accept the fact that I had nobody to give to.

There sure is a lot of self-concept in having kids.

Many of the men interviewed reported feeling a sense of failure; the end of the husband/father role represented more than just a struggle for new identity, but also encompassed a loss of self-esteem. For some, the end of the role as husband/father as they had previously defined it, meant an individual failure, an inability to make something valued highly in society succeed. This in turn precipitated a sense of worthlessness for these men.

When the divorce comes along you say, "Hey, I've been rejected." You feel rejected and you go out and try and find ways to prove you are worthwhile and try and find acceptance on an adult level.

I was a firm believer that I would never be divorced; I could make anything work.

I was never going to let that happen to me. Where did I go wrong? What are my friends going to think?

This was not going to happen to me.

I had to start a new life at 35 , all over again.

The impact loss of identity and loss of self-esteem has on fathering is significant. Whereas before, certain behaviors and expectations were outlined by the father role, the single father no longer has those norms available to him. 
The father struggling with self-doubt and confusion about where he fits into his world must also struggle to redefine the kind of relationship he will have with his child. The old definition is no longer applicable, as much about father has changed, and that has affected everything. In attempting to redefine their new identity, they redefine their role as single fathers.

III. LOSS OF POWER

A reality of the American divorce system -is a loss of power for the male. The fathers in our study describe incidents of powerlessness in a myriad of interactions with their ex-wife and children. Since most of the fathers in our study left their homes and did not have custody of their children, they felt they were at the mercy of the legal system and their ex-wives.

The loss of power has many components and descends upon the man from several directions. The first situation in which the man may experience a loss of power is through involvement in a judicial system that many feel favors the wives' point of view. The area of visitation seemed very significant to these fathers in terms of their powerlessness. Many felt that they had no available instrument to help them achieve their rights.

Well, obviously the major shock about getting a divorce when you have kids is realizing that your kids are being taken away from you; that's pretty hard to take. 
The periods are stretching further and further apart. If I had legal assistance, I would go back to the court. It's just so hard to get help without any money.

I tried several times to see them, but she had gotten a restraining order to keep me from seeing them.

I was never notified when the hearing was. I had made several attempts to find out, because I was going to contest the custody. The hearing was all over before I had time to say anything.

I'm awarded visitation, but I don't get it. There is no mechanism for dads. At least if I can't get custody, at least get fair visitation. I haven't seen my oldest girl but twice in two years.

I can never get enough visitation out of the damn court.

In our society women usually get custody.

If I don't live up to the decree, all she has to do is call the D.A. I have to hire an attorney to see that my rights are upheld.

My attorney told me custody was out of the question. I've thought about it every day since. It's the most important thing in my life. It would cost a fortune.

She can call the D.A. and have me sent to jail. I have to hire an attorney just to go to court and lose anyway.

Along with a judicial system reported to favor wives, the father also feels helpless to counteract the overt actions of his ex-wife. Very often these actions go hand in hand with a "biased" legal system. The father feels at a loss to 
deal with his ex-wife's powerful stance.

They said she will no longer travel on the bus. I've written and suggested alternatives, but they won't do anything--zero.

Christmas, birthday, three weeks in June. I call once a month. When I first got divorced, she told the judge she didn't want me to have visitation rights because I beat her, so the only visitation I was allowed was a couple hours in the park.

My ex-wife said she would lower the support payments if I would agree not to see my daughter.

My wife won't let me come up. She won't let me come up for the boy's birthday.

Everything about the divorce decree has been ignored completely.

She writes me letters back in two or three weeks and lets me know if I can come and visit. When I get there, she shoves my daughter out of the door.

Legally, on paper, I'm to see all three children one whole weekend per month, and the third Saturday, and two dinners per month. That is what it says, but what's really happening is I'm seeing two children about 80 percent of the time.

I don't have my ex-wife's phone number. It's unlisted. I can't call her and I can't call the children.

According to the divorce papers, I had equal visitation rights, but she married some punk ten years younger than her, and he wasn't going to let me see them. She said I'd have to let her know in advance if I was going to come over and visit. I haven't seen them for eight years. 
My ex-wife said sign the kids over for adoption and they would drop all charges for nonsupport.

One day I wanted to take them for three days, but she didn't want them to come. She wouldn't let me see the kids.

After my ex-wife remarried, it ended my relationship with my kids.

I couldn't get my own things--pictures, even though it said so in the decree.

Now she had the power, before I did.

Visitation is up to my wife's discretion.

She won't let me put them to bed.

As well as overt behaviors and statements that prevent the father from relating to his child in a meaningful and desirable way, there is much covert behavior on the part of ex-wives, many fathers reported, that further servesto undermine, intimidate, and render the father powerless.

She enjoyed the fact that she controlled access to the kids. That was her biggest jolly and I imagine she still enjoys it. She did enjoy the psychology of knowing she controlled access to the kids. I still had to go to her turf even though I could see them anytime I wanted.

Now, she has me by the nuts, which says you can't see the kids unless I choose for you to see the kids.

When she wants a babysitter, she drops the kids off. 
Anytime I sent them a birthday present, or a Christmas present, it got sent back.

I asked her to please try and monitor my daughter's television time, because that is a big influence. She said she would, but I don't know how true that is.

It's not the same when they come, they come with all their mother's values.

I don't know how important I am to my kids, they have been drilled with bad things about me.

He bought a car without my knowledge. What she has done is given in to him. She encourages him not to come over. She keeps him from calling me.

The whole court process drug out. I couldn't take the kids, because I didn't want them used. 'My wife would pick their brains when they got home.

My kids knew about the divorce before I did.

When asked who told the children about the divorce, the apparent powerlessness of some fathers was very obvious, again demonstrating the ex-wife's covert power.

I did not tell her.

I told the oldest daughter. I don't know what happened with the little one.

They knew about it before I did. They had been told by their mother.

WeII, it must have been her, it sure as hell wasn't me. 
I don't know. She must have said something. I don't remember.

The kids knew before I did. I didn't even know what was going on.

For some fathers, powerlessness took on a much subtler focus. They felt helpless to impact on their child's life, provide him with direction and support, and help him define the way he would interact with the world.

The problems they are having now have to do with the situation they are in now. There isn't anything I can do.

When they only see me two days out of 30 , it's tough to reinitiate a relationship. How does a kid reestablish rapport with his father?

I just don't know what is happening, it worries me a lot.

You can't discipline a kid you see for one weekend every three months.

I'm not allowed to be involved. It's pretty hard to do anything about it. I see no reason why I shouldn't be allowed to be involved. Whether the court will see it that way remains to be seen.

I was to accept the fact that my wife's new husband would be her new father.

They come with her values and her mother's. My inputs are minimal... can try. I'm just very insignificant. I've really gotten pretty bitter.

I'don't know where the kids are. 
Some of the fathers responded to the frustrations brought on by the loss of power by exhibiting or contemplating extreme behavior. Some fathers became violent in an effort to regain some control, and other fathers simply retreated, feeling that it was easier to. withdraw than to continue the painful never ending struggle.

She wouldn't let me see the kids. I went to court and I went to jail over it.

It didn't do any good to go up there and raise hell. I even shot a cop over it. Yeah, you can't fight city hall.

I would like to have both boys. Oh, it's painful, but you just accept it. You have to.

I took her down and sat on her and that was the first time I'd ever done that in my life.

We had a massive war. I kicked in the door. I took one of the kids.

You think about murder, you think about suicide.

I ended up in jail, put a number on my neck, fingerprints, just like a criminal.' I was mad, that's not even the word. The degradation, humiliation.

Most men give up fighting their ex-wives to see the children. They skip because they don't know what else to do.

The man just doesn't have a prayer. He has to stay and fight or get out.

Powerlessness is a major theme for many fathers 
interviewed. Stripped of what they consider equal rights to fight for what they want, subjected to decisions they may not agree with on the part of their ex-wives, unable to find a means to impact on their child's life, along with the uncertainty of not knowing where they stand and what move their ex-wife might next make, gives rise to extreme frustration, anger or withdrawal. The result of all of this culminates in the way the man is able to relate to his child. A father feeling powerless to relate the way he wants, will find changes in the relationship he once had with his child. The father is now expending considerable energy in combating his powerlessness which would inevitably overflow into his relationship with his child. The father may find the relationship strained where it was once easygoing. He may feel awkward and uncomfortable, and ever present is the reoccurring nagging feeling that the new relationship might also be taken from him.

\section{LOSS OF INTIMACY}

Many of the men reported sadness over not being in a position to be with their children on a day-to-day basis. The routine daily activities, once taken for granted, were missed tremendously once gone from the man's life. How intimacy would be reestablished was a concern for many of these men. The following statements reflect this concern. 
I miss sharing their life. Sharing their life is the most important thing in the world to me.

The largest concern for me was my relationship with my daughter.

I miss the companionship, love, daily contact, being with them.

I miss the communication, having them around.

You can get by without seeing him on a day-today basis if you just hear from them once in awhile.

I liked the closeness. He idolized me. I miss seeing him after work.

I liked our easygoing interaction. The joking, same humor, doing things together--the movies and circus.

My daughter would do things for me and wrestle with me.

Dropping them off was an emotional experience. I would drive for a couple of hours, and then go to a bar for another hour.

Several men mentioned missing watching their children grow and change on a daily basis.

I miss sharing the growing up process.

I don't like living alone. I miss watching them grow; kids are stroking.

I marvel at the changes, the day-to-day growing up that he goes through.

Although most of the men reported a loss in the area 
of intimacy, a few of the men interviewed felt that the resolution of the marital conflict improved their relationships with their children, and in fact, felt closer to them. Without the need to expend energy on the marriage, it was possible to rechannel some of it into the children.

There is a certain part of the week when I can really tun into him.

The relationship is much more personal.

The relationship with my daughter has become more involved. We have quality time together.

We have a neater time, it is more relaxed. Fewer pressures, the relationship improved. Less anger and resentment, more pleasure.

The relationship heightened.

Men missed the intimate contact enjoyed while living with their children. Separation made them more aware that the companionship and affection of their children had been gratifying to them and of how rapidly children develop and change. Continual contact seemed necessary to keep pace with change, and the rapidity of change emphasized the time spent apart.

As a group most of the men in our sample identified themselves as victims; victims of their wives' unpredictability and the court's unfairness, cut off, isolated, forgotten, 
and powerless to do much about evolving a mutually satisfying relationship with their children. They expressed feelings of hopelessness and anguish.

I wanted to jump out of the car and grab them and say let's go, let's run away.

I haven't seen the kids. I couldn't find out any information about my daughter. My wife said it was, "None of my damn business."

The impact of the divorce experience seemed to leave them stuck without much of an identity or self-concept and unable to make much progress one way or the other.

I just couldn't get going. My motivation was gone. I was really pretty well devastated.: I'm still devastated to a certain extent. I just spun my wheels a lot. I just couldn't have fun. There was always the link back. I'd think of the time when "we did it."

The powerlessness led often to feelings of anger and

resentment. There was a lack of self-direction.

There was the central feeling of having the whole world falling apart. I had some thoughts of killing myself--I'll get you.

Just sharing their life is the most important thing in the world. You can't replace it, you can't substitute it, it's just gone. You have to make up your mind about whether you are going to die or live without it. And it leaves a black hole inside. It only left about 10 percent of me. All the rest was black hole. It just destroyed me. You think about murder, you think about suicide. You're just thrown into a no right answer situation, no easy way to go. You've just got to 
take it. I was just completely burned out for a year. In that first year, I couldn't escape enough. I just went on the bum. I had a job for a little while and couldn't hold it. I blew it.

Even though the end of the marriage often meant the end of an unpleasant and unsatisfying relationship, it was still perceived by many as a personal failure:

It was the end of the fantasy that I would never be divorced.

This in turn had a significantly detrimental effect on these men in the role of father. Both overt and covert loss of power was an issue for these fathers. Men described a sense of personal power relative to his child. For many men, the wife's control of access to the children gave her the balance of power in their post-divorce relationship: The shared interest in the child was all that outwardly remained of the marriage, but many men expressed strong feelings of pain, anger and resentment, relative to their former spouse. The unequal distribution of power in relation to the child seemed an extremely troublesome issue for men, interrelated with negative feelings about the former wife, the divorce, dissatisfaction with visitation arrangements or the visitation process.

Men reported, in some cases with considerable bitterness, the ways in which their former wives sabotaged "reasonable visitation," or the court-ordered schedule and prevented their seeing the children. Men perceived themselves 
as powerless to correct the situation through legal channels. It seemed a common assumption that the court would not support father's visitation rights, only his obligation to pay child support. Men were angry and fearful over the tenuousness of their visitation privileges. A new stepfather seemed to be a focus of animosity when problems arose in families where mother had remarried. Mother's moving away sometimes created a considerable barrier to visitation.

In addition to the overt loss. of power with the finalizing of the divorce and control being in the hands of the custodial parent, father feared a covert loss of power. Fathers felt that their former wives at times undermined their status in the eyes of their children. They worried about what was being said to the children in the times between visitations. Were they being portrayed to their children as irresponsible, uncaring or insignificant? They seemed to feel powerless to have much of an impact on their child's life. Some fathers had little confidence that their input was valued or desired.

The divorce experience has a major impact on fathering in terms of the personal crisis for the man and its effect on his ability to function as a parent. The loss of life style, identity, intimacy and both overt and covert loss of 
power, precipitate major adjustments in the way these fathers perceive and adapt to their new role as noncustodial parent. 
CHAPTER V

VISITATION

Dissolution of the family unit is inevitable following a divorce. It signifies the end of an intact family unit. In the American system of divorce, legal restrictions limiting the father's contact with his child following divorce are a reality upon which he has to build a new relationship.

The divorced fathers in our study centered their relationship around visitation, occasional phone calls, and letters. They explored their visitation with us and some specific problems which seemed to make the experience even more complex and difficult. Visitation varied from father to father:

I see them every six months to a year.

Anytime I want; school, creates a problem; but usually about once a month.

Two nights a week and every other weekend.

It varies, one month between visits is the longest time.

Christmas, birthday, and three weeks in June:

Once every four weeks.

We were still having contact till the divorce. It was a strained, artificial situation. 
A number of factors influence the visitation experience. These include poor communication with ex-wife, distance, new relationships, age of the children, and finances.

Most of the fathers felt that communication with their former wives was poor in regard to their children. A few of the men stated they had no communication. Among the fathers that did have communication with their ex-wives, several felt that communication was generally initiated around a problem issue, specifically finances or the child's behavior. Only three of the men in the sample felt their communication adequate.

We communicated poorly. I feared her terribly;

I didn't know what she was going to lay on me.

The only communication we have is when there are problems.

My wife just tells me to take the children, there is mostly a concern about visitation.

We only communicate if my wife needs money.

We communicate only if there are problems.

We would communicate if one of the kids got in trouble.

We don't communicate, letters only.

Good communication.

We communicate by phone and when I take the kids home.

Visitation was limited for some fathers by the distance 
they lived from their children. Both time and expense were factors.

They live in Idaho.

However often I can afford to see them will be the criteria.

It's gotten to the point that the time between visitation has left very little of the relationship left. (Father moved 150 miles away.)

I have not seen them for seven years. (Father moved 3,000 miles away.)

I can't be involved in my child's sports activities because of the distance problem.

Several of the fathers reported that new relationships they established, or their former wives established, affected the relationship with their children. The men in our study talked about the presence of another significant male figure in their children's lives:

I get called Dave a lot by the little one. I don't know. Whether she does it to bug me or not. She says he is stronger than I am, and smarter than I am.

It's very difficult to replace your real father with a substitute father. There is just no substitute for the real McCoy.

He tells me things like, I am lucky to have two Daddys.

My wife is real close with a guy. The kids especially feel divided loyalty. 
I am upset about my wife changing my daughter's last name to her husband's last name. She had done it illegally.

Men saw their own new relationships having an impact on the father/child relationship as well.

The new relationship is a mixed bag. I am moving to Hawaii, but my daughter has accepted this very well. We will change the way we live together, rather than it be a matter of losing contact.

My child was initially brought into conflict between my ex-wife and girlfriend. Now, she makes her own judgment, and is willing to take part in my new family.

I felt kind of guilty about it (my new relationship) and didn't know how to handle it. I knew my first wife would be upset about it; she did not think it was the proper thing for my kids to be around another woman.

The fact that I care about someone is not something I should hide from my daughter.

There were negative feelings when I dated, or stayed at someone's house.

I have lived with a woman who has a child, this has helped because my children see stability.

Both my ex-wife and I have a couple of friends which gives my son some more adults to realte to. The parenting is spread out.

My son became very attached to the gal I was living with.

Age was also a factor influencing the relationship. Adolescents tended to be involved in their own activities, 
and younger children were often difficult to care for over long periods of time. For the men in our study, sex of their chilaren was not an influential factor.

She's very busy with her own activities. She is planning on getting married.

My daughter is really too young to be away from her mother.

He's busy with school and has a part-time job.

All of the men in the study were subject to some kind of restrictions that limited visitation. Some of the fathers did not feel overly confined, but for some the restrictions were difficult to accept. Regardless of the flexibility, all the fathers were required to make adjustments which seemed to affect the relationship they have with their children. 


\section{CHAPTER VI}

\section{THE EXPRESSIVE FATHER}

In our search to define the noncustodial parents' relationship with his children, we first looked at how the father experiences divorce, not only in relationship to his child, but also its overall effect on him; and then at the specific circumstances following the break-up of the family which affected the contact the father made with his child:

The divorce experience, as well as circumstances which confine and inhibit contact, seems to force the father/child relationship to take on new dimensions. The following section will describe and illustrate the aspects of this new relationship.

The role of the American father has moved steadily from the instrumental orientation of earlier generations to a more expressive orientation as the family as an institution has lost many of its functions. For the purpose of discussion, we will define instrumental functions as parenting activities which aid the child's physical and social development, other than the expressive functions which represent emotional involvement as an end in itself.

We found the divorced father left with few of his instrumental functions as a parent. Consequently, father placed increased emphasis on his expressive functions within 
the father role. He is preoccupied with questions such as, how does my child feel about me? How do. I feel about my child? What is the mother saying about me to the child? Am I of significance to my child? Without his instrumental functions, the divorced father is a less powerful figure in the life of the child.

Fathers expressed concerns about the child being able to manipulate him, fears of rejection by the child, and a continual need to please the child. The child remains the only tie the father has to the familiar life that he had as a married person. As fathers described their emerging expressive role, certain themes reoccurred. These themes included: fathers' idealization of their child; the father as entertainer; the child as emotional support for the father; and an emphasis on enhancing communication and closeness.

In order to illustrate the movement from an instrumental orientation to a more expressive orientation, we contrast the information the fathers provided about their involvement and interaction with their child to divorce, and their description following divorce:

Prior to divorce, we were interested in how these fathers conformed to the traditional father role, and how they perceived their relationship.

Foremost in the role of the traditional father is the function of provider. Our fathers describe this function as 
basic to fatherhood.

I would work late, I had a part-time job.

The demands of teaching, left little energy left.

of course, I was the breadwinner and that automatically sets the pattern.

I was the meal ticket and the hatchet man.

I spent little time with the children. I was working and going to school.

Mainly I worked.

I was working all the time.

The fathers in this study described themselves as the primary disciplinarian in the family, conforming to the role of traditional father. Eight fathers described themselves as primary disciplinarians; four stated they shared the discipline with their wives, and three saw their wives as the primary disciplinarian.

I was the primary disciplinarian. I had a traditional upbringing.

She was a yeller and I was an authority figure.

I was the primary disciplinarian, the wife saved up discipline problems.

My wife had no power and no control, I used the belt.

We shared equally. 
My wife was mostly the disciplinarian.

Four men stated they did not have anything to do with the physical care, citing work or outside activities as conflicting with physically caring for the children.

Most of the fathers in the study had daily contact with their children, and describe their weekend activity as being directed toward family activities. Activities included recreation, home maintenance, T.V. and reading time together.

In conclusion, our sample was fairly consistent since all the men were working and were the major family providers. They also described the task of disciplinarian as usually falling to them as fathers. Most of the men felt they shared the physical care, and that their free time was usually centered around family activities.

In talking with fathers about some of the dimensions of their new relationship, they seemed to share a tendency to idealize both their child and the relationship between father and child prior to divorce. Fathers tended to describe their children as exceptional in terms of adjustment, behavior and personal attributes. Fathers saw their parenting role before divorce as problem-free and their children as very easy to manage.

There was never a problem. They were good kids, they were exceedingly good kids. Parenting has always been a dream for us. It was an absolute Camelot and we played on it. 
I have never spanked her. She does exactly what I tell her.

She is extremely bright, perceptive and intelligent.

I can't think of anything I would want to change. She was such a well-adjusted child. There was nothing I wanted to change.

I can't think of anything I would want differently.

The relationship was great, it was great! I don't know what else you could say. It was just wonderful.

My kids are brighter than me. My kids are more sensitive than me.

She was the kind of child you would want to take anywhere. (age 1)

Although there were exceptions, the overall pattern was one of idealization of the child and his behavior prior to divorce.

Both the literature reviewed and the fathers in our study reported that entertaining the child was a major component of their role after divorce. As father's instrumental functions are eliminated, he seemed to need to find other forms of involvement with his child. Father is now seeing his child in an entirely different context and situation and perceives a need to provide activities to structure the time. Lack of ongoing contact contributes to the problem of knowing what to do with the child. He seems to have a need to assure that 
the child will find the visit pleasurable and does so by concentrating on having fun together.

The following were responses to, "What was your last contact with your child?"

We had a pizza party.

We played chess and ping pong.

The last contact was Thanksgiving.

They stayed all night, we went out and ate, and then to visit my mother.

We ate pizza.

We watched T.V., went to a movie, played chess and darts.

We went camping.

We went to church and played baseball.

We went on a ferryboat ride across puget Sound.

We had dinner and went to stores.

We spent Christmas together.

We went shopping and checked out book stores.

Some of the fathers described their dilemma in arranging the time spent with their children when visiting.

It is difficult, the only one I see now is the older one. It is a problem to know how to entertain him. It is difficult to have a boy 
for two or three hours and know what to do. He looks to me as having an endless supply of money.

It is more like a vacation, recreational. We talk about the other things going on, but it is more vicarious.

There is a tendency to go out for entertainment type things rather than stay around the house.

The relationship with the children is different because Mommy is never around. It is tough to find activities.

I wish there were things that we could do that were relaxing, that would mean more.

We travel more and go more places with other people. There is more planned activities.

Many of the fathers in our study saw that the relationship they had with their children was unique from the standpoint that their children acted as resources, providing emotional support and friendship in the relationship. These men saw that this aspect was present not only following divorce, but also previous to and during the divorce period. Fathers placed great significance on the role the child played in relationship to him, describing their children as best friends, buddies and counselors.

The following statements illustrate how several fathers described the element of friendship when discussing their relationship with their child.

Your kids become buddies of yours. 
My best friend is my number one son.

That little girl and I, well, we became best friends. She was my best friend in the whole world. And I was her best friend in the whole world. There is no doubt that we were best friends.

I used to spend all my free time at home with my daughter.

We just did everything we could together. I mean, I couldn't even go to the store without them. We were really close.

My kids were my favorite people:

Some fathers felt that their children literally carried them through the divorce process, providing companionship and emotional support. Fathers saw the relationship with their children as central in their lives, and described great attachments. The following statements illustrate this aspect of the relationship.

I just lived for my daughter.

I went recluse. I hid and never dated. I just hid behind the kids.

The kids went out with me to find my apartment. I picked the one of their choice. They helped me move.

My kids kept me clean, they treated me normal, otherwise I might have oD'ed.

My kids saved my ass.

My kids carried me through my divorce. 
Children are the only immortality.

Nothing ever affects my relationship with my daughter. One thing women understand right from the beginning is that my daughter is the most important thing in my life. If it came right down to another person and my daughter, my daughter would win hands down.

My daughter is my entire life, she is everything. She always has me no matter how often my wife remarries.

Just sharing their life is the most important thing in the world.

Those kids are the most important thing in the world.

Intimacy as a component of the father-child relationship was given a great deal of emphasis by most of the divorced fathers. The men identified intimacy, particularly communication, closeness, sharing physical affection and verbal exchanges of affection as important parts of their involvement with their child. Some men reported being very satisfied with the level of intimacy between themselves and their child. Other men expressed a desire to strengthen those aspects of the father-child relationship. Fathers felt they should provide their child with understanding, acceptance and unconditional love. Men noted that the relationship had become more intense due to focusing on the child during the limited amount of time they had together.

The relationship is much more personal. The relationship with my daughter has become more involved. We have quality time together. 
There is a certain part of the week when I can really tune into him.

I am more sensitive, the day-to-day concerns are gone, I am sensitive to proximities.

I like the flow between us, the person-toperson relationship. Her willingness to share her openness and acceptance of me.

I like seeing her, it is the warmth and love between father and daughter.

I wish I had maintained contact with the kids. It's been so long,. I don't know how I feel about them. I don't even know if I would like them. Maybe I am afraid to see them. Maybe they would not like me, or I would not like them.

We have barriers to close. I wish she were here more, it would change the problems about us.

I can communicate and talk with them.

I wish it were easier to communicate. I wish it were easier to talk.

We asked men to describe how they communicated their feelings about their children to their children. Most of the fathers cited expressive behavior as showing their children that they cared.

I communicate it through physical touching and accessibility, and interest, unconditional acceptance.

I communicate it through body language, kissing and hugging.

I tell her I love her. 
They know how I feel about them. We touch, we hug.

I say I love you. She holds me a lot...

I show them through touching, smiles, tickling.

We ki'ss and hug.

I show them affection.

Expressive orientation was also clear when fathers

compared their own parenting to that of their fathers.

I'm more like my mother in terms of affection.

I am less rigid than my own father.

I show my child much more love and affection than my own Dad did.

I am more a communicator than my step-father. I would do more things with my daughter; I'm more accessible to the children.

I wasn!'t as critical, I tend to be very positive about practically everything my child does. I don't take my values and say this is what you have to do. If anything, I would accept something from my child, if I thought it was less than she could do.

I am more affectionate.

I am a lot warmer, and I show emotions. I provide validation.

Fathers also shared with us their image of a perfect father. Their statements included the importance of expressive 
components in the relationship.

A perfect father gives you free choice and does not try and brainwash you into their value system.

You let your own child be free enough to have his own personality and develop it within certain guidelines.

Characteristics of being very unconditionally caring. Being available, not preoccupied. Being unconditional and accessible are the two most important things.

Intimacy is an important aspect of fathering.

The key element is being willing to accept what is happening, not try to mold the child, being supportive.

Dependable, empathetic and communicative are the most important things.

Having a commitment to the kid. The ideal father is self-accepting, growing, in touch. with his own feelings, sensitive to the child, is supportive and able to get into the child:

He needs to be accepting and to share.

He is consistent, loving, listens, is selfaware, and gives unconditional love.

Part of being a father period is paying attention to your kids. I spend a lot of time listening to my daughter, that is the majority of it right there. Paying attention to them.

An ideal father is gentle, kind, gives hugs, prayers, is loving and wise. 
He spends time, is a friend, gives incentive, someone to look up to and be proud of.

He understands, trusts, and communicates.

In a final attempt to discover the father's perception of his significance to his child, we asked each of the fathers in our study to tell us, "How important do you think you are to your child now?" It seems of interest to add at this point that the authors noted when listening to the tapes, that all of the fathers had difficulty in responding to the question.

Part of me says that I am the most important person, but I don't really know. I guess every parent wonders. I am idealized by distance. He does not need a father 24 hours a day, 7 days a week anymore than he needs a mother.

I don't think I am as important, because he is in a family situation. He will always know who I am. I feel important, but if I wasn't here it would not be very difficult for him.

Not as important an influence as if. I was living with her, but I am important in the idea of having a father. At least there is a male image.

Probably no importance: On a scale of 0 to 10 , probably 0 , maybe 1 .

There is lots of negative feelings. I am important, but I mistreated her.

It is a good question, I don't know, I don't worry about it though. I know the time will come when I will be very important. I try not to force myself on them. It would be disastrous if I did. 
I am worried about that. She is a11. I've got. I used to think that if I really was not that important, it would be better to have her be adopted because it would be cheaper for me in the long run. But you just don't sell your kid.

I can't answer that. My image is important, I am sure. I am important, but I don't know how.

The love me, but as far as the day-to-day kinds of things are concerned, I am not that important.

I don't know. I think under all the' layers of frustration and confusion and pain, underneath... I am important.

Probably with my son somewhat. But with the other two, only if they needed something.

I don't know. The kids have been drilled with bad things about me.

Within these fathers' statements we found confusion and contradiction. There seemed to be a lack of clarify as to whether their importance to their child was real or how they wished reality to be. 
CHAPTER VII

\section{CONCLUSION}

The divorce experience as perceived by the fathers in our study had a major impact on fathering. The emotional impact and social consequences of divorce have left many men confused and frustrated in their role as father. The shift in power from father to his former wife and the child seemed to leave father feeling angry and impotent.

An initial effect of divorce, as reported by most men in our sample, was an overwhelming experience of loss. This seemed to effect the man's sense of identity and purpose. Many, felt lonely and alienated. Resentment and ifrustration were common emotional responses. The men in our study experienced difficulty moving from a married to a single lifestyle. The multitude of changes involved in this move culminated in a new relationship with their child.

Fathers discussed visitation and.its impact on their interaction with the child. They described the difficulties of establishing a new relationship with the child within the framework of prescribed visitation arrangements, the difficulties of communicating with the former wife and maintaining a sense of continuity in the relationship with the child. Throughout the discussion, the theme of desire for intimacy and an emotionally supportive relationship with the child 
was very much in evidence.

For the fathers interviewed, one of the outcomes seemed to be a movement toward a more expressive role, expanding the father-child relationship into a new dimension. The quality of the relationship, and how the father and child related, was emphasized rather than the more traditional instrumental activities of provider, disciplinarian, and teacher.

The lack of social sanction and support for the role of divorced father appeared to add to the confusion and frustraof the men interviewed. Their struggle to define their role and relationship with their child seemed to be given little recognition by the community. Although there is some evidence of increased interest in the role of divorced father in newspapers and magazine articles, he is still seen as a very peripheral figure by child welfare or mental health agencies, schools and other agencies concerned with families.

\section{IMPRESSIONS}

The researchers formed a number of general impressions about the behavior of the fathers interviewed. These men were often preoccupied, even after considerable time, with their former wives and the angry feelings which they evoked. At times intense anger was directed at the legal system, the wife's new spouse, or former in-laws. Some men reported incidents of violent behavior, which they saw as being precipitated by the divorce experience. Thoughts of suicide and evidence of severe depression were also reported by several 
men interviewed. Regressive behavior, such as increased contact with parents, hasty attachments, and excessive sleeping were reported by men in the period after divorce. It took some men over two years to regain a sense of equilibrium. The researchers perceived a sense of emotional deprivation in some newly divorced men, which may be causally related to their desire for intense, intimate relationships with their child. Perhaps father's desire to provide unconditional love reflected his own need for gratification from the child. Physical affection seemed a very important issue to these men.

When looking back at the relationship these fathers had had with their children prior to divorce, there was a tendency to exaggerate all the positive aspects of the child and deemphasize the negative. As a whole, they seemed to feel they had been a "good" father, better than their fathers had been, and most regrets seemed to center around the conflict between husband and wife, and it's negative impact on the child. These fathers appeared fearful of rejection by their children and felt they could be easily exploited by them.

The experience of divorce tended to leave many of the fathers bewildered and unaware of some options or alternatives which, if implemented, may have sustained a more intimate and constructive relationship.

We sensed an "unwritten" choice for the men that affected the role of the noncustodial father: If you can't 
take being less important, detach completely. Although many described their children as the most important thing in their lives, several had chosen to move a great distance away. New marital relationships seemed to play a role in detachment for some. One could speculate that as the father's emotional needs were met in other ways, he was better able to cope with the loss of his child.

The authors were impressed by the overall furor directed toward the legal system by the fathers in the sample. This included the attorney, the court system, and the law pertaining to child custody (including how they were administered).

Although our interview schedule was not directed at the role of the attorney, or inequities in the legal:system, the men in our sample seemed to feel that they played a major role in his dilemma -- deterioration of the father-child relationship, frustration, and powerlessness. Most of the fathers described their lawyers as having discouraged them from even attempting to gain custody of their children, and that they did not receive adequate information from their attorneys, describing alternative custody situations, or the problems or pitfalls of the "reasonable visitation" clause in the divorce decree. One man described his attorney as "God," in that he made all the decisions regarding the divorce and just told me "custody is not an option." Many of the fathers wished they had fought harder to get an equitable agreement at the time of the divorce, but felt that they were just too 
upset and lacked the knowledge as to how to go about it. They saw divorced men in general as being at the mercy of the attorney's particular whims.

Most of the fathers saw the inequity happening after divorce was finalized. If the wife did not live up to her part of the arrangement, the husband would have to hire an attorney to fight her possibly at considerable cost. However, the wife could simply call the police if the support payments were not made on time. They could also have no influence as to how the money was to be used. Most of the men felt that the system, when children are involved, favored the woman so much that information which she gave the court was taken at face value and difficult to disprove.

\section{CRITIQUE OF STUDY}

At this point, the researchers will attempt to give a critical examination of the preceding study. As our study developed, we became aware of some of the major changes which would have added to our efficiency, increased the information gathering potential, and reduced the biases.

Our sample cannot be considered in any way to be representative of the noncustodial father in this country. It was biased heavily in the direction of the highly educated white-collar, Caucasian sector of our society. The authors in no way support the premise that the information received in our study would follow through other categorical breakdowns within the overall population. Due to the bias in our sample, 
most of the men were highly skilled verbally and had little difficulty in describing their personal experiences. Also, many of the men in our sample were involved in self-help programs and were eager to be involved in the study, since they felt that there was a need for research in this area. The researchers feel that the use of three women to do the interviewing could have biased the responses given by the men and limited the amount of information given. There was also a lack of consistency in the location in which the interviews took place. The location had to be varied for the convenience of those interviewed.

We found the questions asked often too broad in scope; which while allowing for flexibility and encouraging new material, made it difficult for the interviewers. to keep the interview focused. Fewer openended questions with a more limited scope would have been more effective in developing information in specific areas of interest.

Our question as to, "The child receiving the father's values," could have been eliminated. 'It did not yield information, because it seemed to confuse most of the interviewees and many felt that even a father living with his children could not possibly answer that question.

The question in section two as to, "The major concern of the fathers at the time of divorce," was not clear to most of the fathers, and required considerable explanation by the interviewers.

The researchers found that using taped interviews was 
extremely valuable as a method of obtaining data. However, it tended to make for a lengthy and tedious analysis.

\section{III.' SUGGESTIONS FOR FURTHER STUDY}

Part of the intent of the researchers in attempting to get an overall look at the impact of divorce on fathering in an exploratory survey was to delineate areas for further and more focused research. The following are suggestions which the researchers have identified as areas in which a more specific and in-depth study could be made:

- The role of the attorney in the divorce experience.

- The length of time divorced fathers take for recovery after the divorce.

- The fathering role in contemporary America, with emphasis on tracing the fathering behaviors from the previous generation.

- Influence of mother in the relationship of the divorced father and his child.

- Changes in relationship of divorced father and child over time.

- Nature of relationship between divorced father and adolescent child.

- Effect of remarriage of either party in the relationship between divorced father and child.

- Sources of support for divorced fathers: PWP, Solo Center, etc.

- The communication process related to the child between the noncustodial father and former spouse.

- Evaluation of joint custody's effect on children.

- Psychological implications for the relationship of the power shift between father and child.

- Age of child as a factor in post-divorce relationship. 
- Significance of child in life of divorced males.

IV. IMPLICATIONS FOR SOCIAL WORK

The social work profession is consistently concerned with the function of the family in contemporary America. The ramifications of the dissolution of that unit, specifically, impact of the divorce experience on fathering, hold considerable significance for the profession. This significance is two-fold: It affects the relationship between father and child, and it impacts on the role the father has as an adaptive and stabilizing influence in the life of the child in meeting his needs for individual growth and socialization. We need to be more aware of the divorced father's actual and perceived stumbling blocks to developing a consistent and meaningful relationship with the child. Support systems for the divorced father need to be more visible and accessible in an attempt to maintain the quality of the father's life and that of his child.

The view that one of the other party in a divorce must be "wrong" and the stereotype of the "swinging bachelor" are very common misconceptions, which tend to draw support away from father. Given the contribution of fathering to the growth and development of the child and the prevalance of divorce in our culture, it would seem imperative that the 
father-child relationship be encouraged and that the role of the divorced father be given support and recognition by the community.

We need asa professional group to take a stance as to the significance of the role of father in the development of the child, and support legislation which would promote it. 


\section{BIBLIOGRAPHY}

REFERENCES CITED

Atkin, Edith and Estelle Rubin.

1976

Part-Time Father. New York: The

Vanguard Press.

Benson, Leonard.

1968

Fatherhood: A Sociological Perspective.

Biller, Henry and Dennis Meredith. 1974

Father Power. New York: David McKay, Inc.

Cassidy, Robert. 1977

"Till Divorce Do You Part," The Oregonian, March 8, 9, 10.

Dodson, Fitzhugh. 1974

How to Father. Los Angeles: Nash Publishing.

Egleson, Jim and Janet Frank Egleson.

1961 Parents Without Partners. New York:

E. P. Dutton.

Fasteau, Marc Feigen.

1974 The Male Machine. New York: : McGraw-Hill.

Gettleman, Susan and Janet Markowitz.

1974

The Courage to Divorce. New York:

Simon \& Schuster.

Gilder, George.

The Naked Nomads.

Hardy, Richard and John C. Cull.

1974

Creative Divorce Through Social and

Psychological Approaches. Springfield,

Illinois: Chas. C. Thomas.

Hetherington, E. Mavis, Martha Cox and Roger Cox. 1977

"Divorced Fathers." Psychology Today,

Vol. 10, No. 11, April.

Howe, Louise Kapp. 1972

The Future of the American Family. New York: Simon \& Schuster. 
Hunt, Morton M. 1966

The World of the Formerly Married. New York: McGraw-Hill.

Krantzer, Mel.

1973

Creative Divorce. New York: M. Evans.

LeMasters, E. E. 1970

Parents in Modern America. Homewood, Illinois: The Dorsey Press.

Weiss, Robert.

1975

Marital Separation. New York: Basic Books, Inc.

ADDITIONAL SUGGESTED READINGS

Bach, G. R.

1946

"Father Fantasies and Father Typing in

Father Separated Children," Child

Development, Vol. 17.

Bernard, Jessie.

1975

"Note on Changing Iife Styles, 1970-1974,"

Journal of Marriage and the Family, Vol.

37, No. 3, August.

Bigner, Jerry.

1970

"Fathering: Research and Practice

Implications," Family Coordinator, Vol. 19.

Burgess, June $\mathrm{K}$. 1970

"The Single Parent Family," The Family Coordinator, Vol. 19.

DeFrain, John D. 1974

"A Father's Guide to Parents" Guides: Review and Assessment of the Paternal Role as Conceived in the Popular Literature." ERIC, 19 p.

Demos, John.

1974

"The American Family in Past Time," American Scholar, Vol. 43, No. 3.

Freudenthal, Kirt. 1959

"Problems of the One-Parent Family," Social Work, Vol. 4. 
Glasser and Glasser. 1970

Families in Crisis. New York: Harper and Row.

Green, Miles. 1977

"Children More Resilient Than Parents Think." The Oregonian, January 25.

Grollman, Earl A. 1969

Explaining Divorce to Children. New York: Beacon Press.

Hill, Reuben and Howard Becker, Eds. 1955

Family, Marriage and Parenthood: Boston.

Jackson, Don and William. 1968

The Mirages of Marriage. New York: Norton.

"Girls Without Fathers: The Impact of Divorce and Death," Psychology Today, February.

Kotelchuck, Milton. 1972

"The Nature of the Child's Tie to His Father," PhD dissertation, Dept. of Social Relations, Harvard University.

Lynn, David B. 1974

The Father, His Role in Child Development. Monterey, California: BrooksCole Publishing Company.

Mobley, E. David. 1975

"Ego Ideal Themes in Fatherhood," Smith College Studies in Social Work, Vol. 45, June.

Molinoff, Daniel D. 1977

"Men's Rights Groups Fight to Change Divorce Laws," The Oregonian, April 3.

Nash, John. 1965

"The Father in Contemporary Culture and Current Psychological Literature," Child Development, Vol. 36.

Parsons, T. 1955

\footnotetext{
"Family Structure and Socialization of the Child," Family, Socialization and Interaction Process.
} 
Payne, D. E. and P. H. Musseu.

1956

"Parent-Child Relations and Father Identification Among Adolescent Boys," Journal of Abnormal and Social Psychology, Vol. 52 .

Polatnick, M. 1973-74

"Why Men Don't Rear Children: A Power Analysis," Berkeley Journal of Sociology, Vol. 18 .

Skolnick, Arlene and Jerome H. Skolnick. 1971

Families in Transition. Boston.

Spricer, Jerry W. and Gary D. Humpe. 1975

"Kinship Interaction after Divorce," Journal of Marriage and the Family, Vol. 57, No. 1, February.

Stuart, Irving R, and Lawrence E. Abt. 1972 Children of Separation and Divorce. New York: Grossman.

Wohler, Milly. 1977

"Study Reveals Divorce May Not Be Harmful to Children," The Oregonian, January 25. 
APPENDIX

I. DEMOGRAPHIC VARIABLES

1. What is your age?

2. What is your occupation?

3. What is the last year of school you have completed?

4. How long were you married?

5. When were you divorced?

6. Have you remarried?

7. How many children do you have?

8. What is the sex of your children?

9. What is the age of your children?

10. Do you contribute financially to their care?

11. Has your former wife remarried?

12. Where do she and the children live?

13. Did you ever consider seeking custody of your children?

II. RELATIONSHIP AND ROLE PRIOR TO DIVORCE

14. We are now going to ask you some questions about your daily life with your children:

a. How did you and your former wife share the physical care of your child?

b. How much free time did you find you were able to spend with your child? 
c. What did you do during that time?

d. Who was the primary disciplinarian in your family?

e. What do you miss the most?

f. Can you tell us anything else about the daily routine with your child?

15. We are interested in knowing how your life has changed since your separation. Can you comment on this?

a. Have you maintained many of your mutual friendships?

b. What has changed in your living situation?

c. Are you spending your free time differently?

d. Is the time spent with your child spent differently?

e. Is there one major issue that stands out at the time of your separation?

16. Have you found your own family to be a resource for you and your children?

17. Who told your children of the divorce/separation?

18. What did you tell your children?

19. Have you talked with them since then about the divorce?

20. Have you sought professional help regarding concerns about your children? If so, what were the major concerns?

21. What did you like and what did you wish were different while living with your children?

22. What was your own father like?

23. Do you see any similarities or dissimilarities between yourself and your own father?

24. Could you describe your ideal of a perfect father? 


\section{PRESENT}

25. We would now like some information about what is happening with you and your child:

a. How often do you see them?

b. How is visitation arranged?

c. How do you decide what you are going to do when you are with your child?

d. Describe your last contact with your child?

e. Occasionally, divorced fathers participate in school conferences, sports events, extracurricular activities, do you find opportunity to do these things?

f. Are the children more difficult for you to manage since the divorce?

g. Do you feel differently about disciplining the children now?

26. Can you tell us a little about how you and your former wife communicate about the children?

27. How has your new relationship/remarriage or your wife's new relationship/remarriage affected your children?

28. How important do you think you are now to your children?

29. Does your child know how you feel about him?

30 How do you communicate how you feel about him to him? 